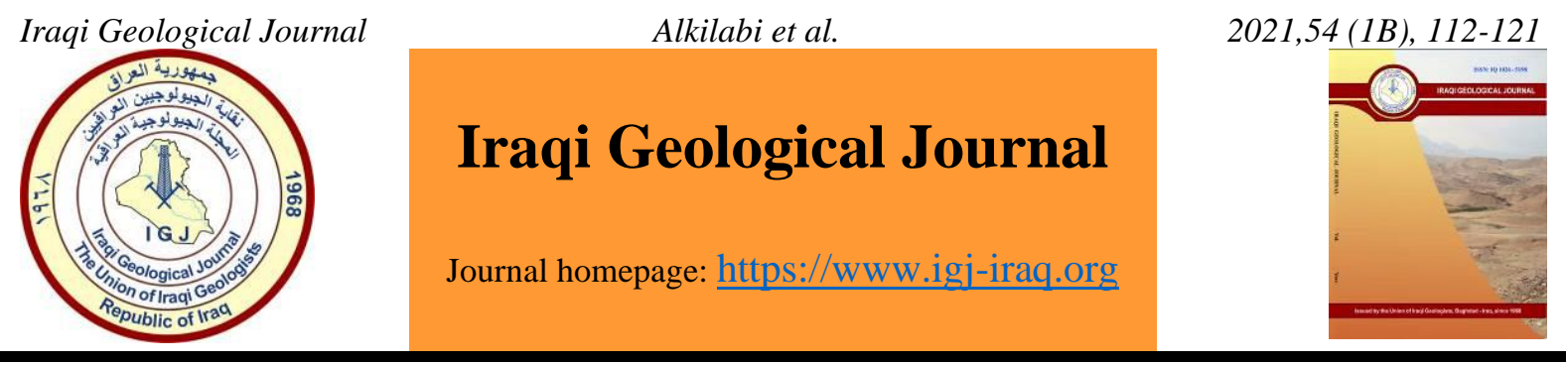

\title{
Water Quality Evaluation of Selected Springs in Qazania Area, Diala Governorate, East Iraq
}

\author{
Joudah A. H. Alkilabi ${ }^{1, *}$, Qays K. N. Alkhlidy ${ }^{1}$ and Nidhal H. Khaleefa ${ }^{1}$ \\ ${ }^{1}$ General Commission for Groundwater, Ministry of Water Resources, Baghdad, Iraq \\ * Correspondence: jodahaefan@gmail.com
}

Received: 2 July 2020; Accepted: 24 December 2020; Published :28 February 2021

\begin{abstract}
Twenty-five spring water samples were collected from the study area and analyzed for major constituents' concentrations $\mathrm{Ca}^{2+}, \mathrm{Mg}^{2+}, \mathrm{Na}^{+}, \mathrm{K}^{+}, \mathrm{Cl}^{-}, \mathrm{SO}_{4}{ }^{2-}, \mathrm{HCO}^{-}$and $\mathrm{NO}_{3}{ }^{-}$. The parameters of $\mathrm{H}$, TDS and EC were measured as well. The springs water is neutral to slightly alkaline, Piper's diagram classification indicates that most samples are earth alkaline water with an increase portion of alkali with prevailing sulfate and chloride. A Dominant cation is sodium followed by calcium then magnesium, while sulfate is a dominant anion followed by chloride, bicarbonate then nitrate. The dominant water type is $\mathrm{NaSO}_{4}$ which represents $64 \%$ of all samples followed by $\mathrm{NaCl}$ type which represents $28 \%$ and $\mathrm{CaSO}_{4}$ type which represents $8 \%$ of all samples. According to Water Quality Index (WQI) classification, $24 \%$ of whole samples are excellent, $8 \%$ is good, $24 \%$ poor and $44 \%$ are unsuitable for human drinking. According to Richard diagram, $20 \%$ of all samples have been fallen in C2S1 class where they are good for irrigation, $68 \%$ of all samples have been fallen in C4S2 class where they are poor for irrigation and 8\% of all samples have been fallen in $\mathrm{C} 4 \mathrm{~S} 3$ class where they are very poor for irrigation, therefore it is clear that the most springs samples are not suitable for irrigation purposes except for very salt-tolerant plants.
\end{abstract}

Keywords: Qazania; Spring water; Piper Diagram; Water Quality Index; Irrigation; Richrd Diagram

\section{Introduction}

Water quality depends on many factors which include geology, degree of chemical weathering of prevailing lithology, quality of recharge water as well as water-rock interactions (Dikeogu et al. 2018). Groundwater becomes a primary and important resource in many areas of the world, so it is important to study its quality and quantity to identify its suitability for drinking, irrigation, industrial and other usages (Scanlon et al. 2006). Numerous studies established on the perspective of understanding the influence of groundwater availability on multiple hydrological and environmental aspects (Ali and Abdel-Hameed, 2018; Das and Pal 2019; Niaz et al. 2018; Pande et al. 2019 in Awadh et al., 2019). Groundwater is an essential natural water resource that supplies the population for different uses as in domestic, agricultural and industrial purposes, where it provides about half of all the freshwater used worldwide (Shiklomanov, 1996 and Chilton et al., 1994 in Awadh et al., 2016). Few researches were carried out on the springs in this region although tens of those springs are existed, probably due to the fear of the presence of military remnants from the Irani-Iraqi war. Parsons (1955) mentioned that there are numerous springs in the Khanaqin-Jassan area, which mostly parallel to the low hills zone along the

DOI: 10.46717/igj.54.1B.10Ms-2021-02-28 
Iranian border. Those springs apparently originate at the intersection of the water table with the ground surface, where the transitional slopes from the low eastern hills flatten to form the alluvial plain to the west. Sissakian et al. (2017) studied the characters and types of alluvial fans in the middle and eastern parts of Iraq. There are many alluvial fans in Mandili vicinity and differentiated into five stages depending on tone, drainage density, drainage type, materials of the top cover and cultivation density. Al-Sudani (2018) studied the hydrochemical evaluation and utilization of groundwater in Khanaqin area. The study of Fakhre and Abdulhussein (2020) showed that the hydrochemical properties of groundwater and some springs in Qazania area, their results showed that the water wells and springs are highly mineralized and characterized by low alkalinity and very high hardness the research aims to evaluate the chemistry of spring water in Qazania and recommended to human different life utilizations.

\section{Study Area}

Qazania is a part of Mindili County which locates in Diala City. The study area lies between the latitudes $33^{\circ} 20^{\prime} 00^{\prime \prime}-33^{\circ} 39^{\prime} 00^{\prime \prime}$ and longitudes $45^{\circ} 33^{\prime} 00^{\prime \prime}-45^{\circ} 57^{\prime} 00^{\prime \prime}$, which cover area of $767 \mathrm{~km}^{2}$. It was delineated on the Iraqi-Iranian border. Mandili locates to the north, Tursak toward the west and Dilala-Wassit toward the south (Fig. 1). Springs located at the ends of alluvial fans and recharged from the east where outcrops of geological formations. The main aquifers are Bai Hassan, Mukdadiyah, Injana, and Fatha formations, these aquifers consist of different materials and have different permeabilities therefore they have different effects on the quality of water.

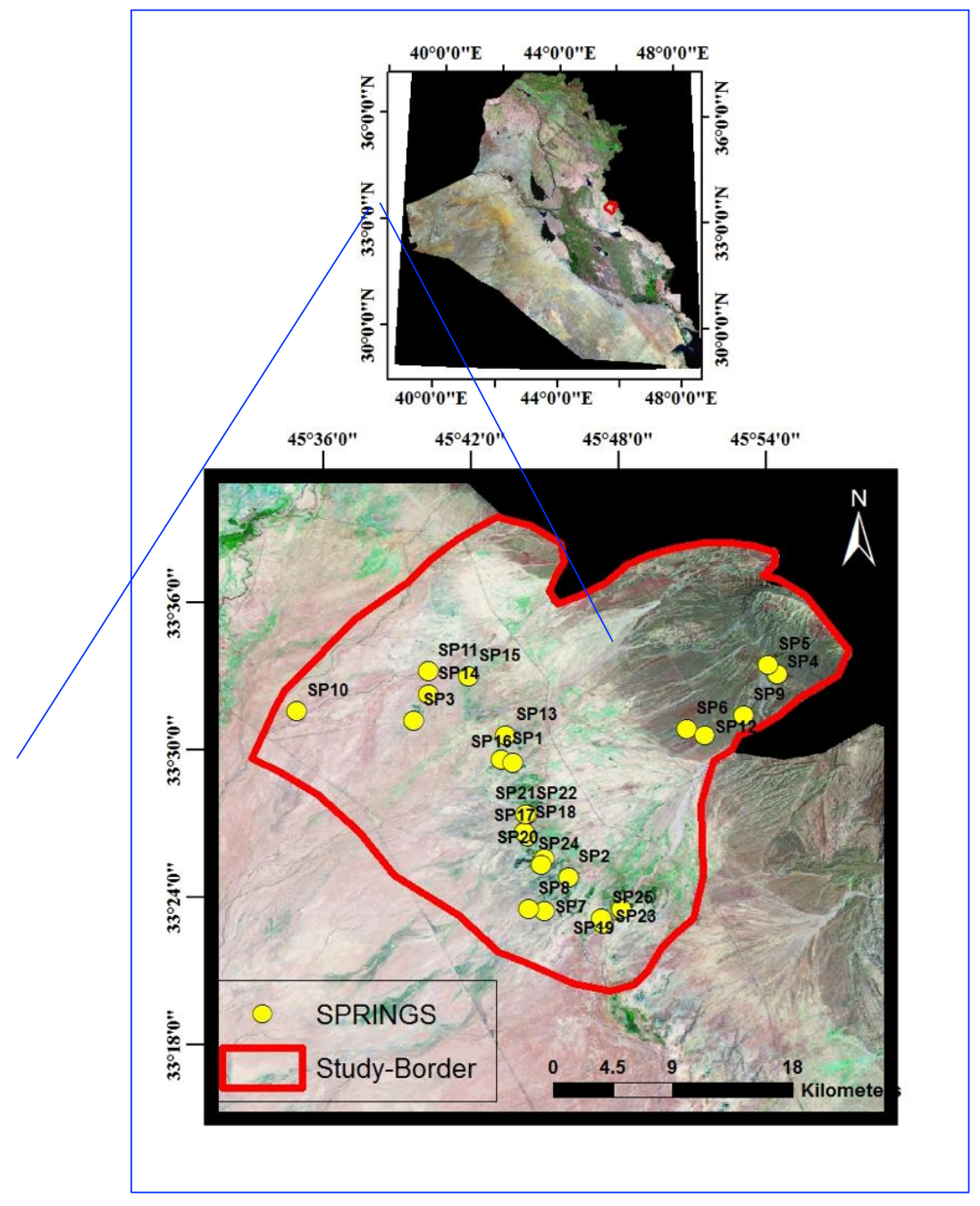

Fig. 1. Location map of the study area 


\section{Stratigraphy}

According to Barwary (1991), the geological formations in the study area from younger to older are quaternary deposits then Bai Hassan, Mukdadiyah, Injana, and Fatha formations. Quaternary deposits represented by slope deposits, valley deposits and alluvial fan deposits consist mainly of gravel, sand, silt and clay. Bai Hassan Formation is composed of conglomerate, claystone and some sandstone. Claystones are predominant in the upper part. Conglomerates are massive loose, compacted, composed of gravels of different colour, shape, size and composition. The Mukdadiyah Formation is composed of alternation of medium-coarse grained sandstone, siltstone and claystone beds. Sandstone beds are containing very often pebbles. The Injana Formation is composed at monotoneous alternating at sandstone, claystone, and siltstone beds. Sandstones beds become thicker, less compacted and coarser upwards. Clay-stones are brownish, fractured, silty, and containing often lenses of siltstones and/or sandstones. The Fatha Formation consists of two members. Both members are cyclic in nature. Each cycle starts with claystone followed by marl, thin limestone and thick gypsum on the top. They are alternating in regular order.

\section{Materials and Methods}

Twenty-five springs were selected to collect water samples in October 2019. Springs locations were dropped by portable GPS instrument. Samples were collected by pre-cleaned polyethylene oneliter bottles, which are rinsed with water before filled. Springs samples were sent to the laboratory of the General Commission for Ground Water in Iraq to analyze for main cations and anions $\mathrm{Ca}^{2+}, \mathrm{Mg}^{2+}$, $\mathrm{Na}^{+}, \mathrm{K}^{+}, \mathrm{HCO}_{3}{ }^{-}, \mathrm{Cl}^{-}, \mathrm{SO}_{4}{ }^{2-}$, and $\mathrm{NO}_{3}{ }^{-}$(Table.1). $\mathrm{Ca}^{2+}$ and $\mathrm{Mg}^{2+}$ were analyzed by Titration with EDTA, $\mathrm{Na}^{+}$and $\mathrm{K}^{+}$were analyzed by Flame photometer instrument, $\mathrm{HCO}_{3}$ is analyzed by titration with $\mathrm{HCl}$ using phenolphthalein and methanol $60 \%, \mathrm{SO}_{4}{ }^{2-}$ analyzed by titration with $\mathrm{BaCl}_{2}$-EDTA using Eriochrome black-T indicator, $\mathrm{Cl}^{-}$analyzed by titration with $\mathrm{AgNO}_{3}$ using potassium chromate indicator and finally $\mathrm{NO}_{3}{ }^{-}$analyzed by using UV-Spectrophotometric method.

\subsection{Mathematical Equations}

To make sure the accuracy of chemical analysis, it was adopted the cation-anion balance using equation below:

R.D $\%=100 * \mid\left(r \sum\right.$ Cat $-\mathrm{r} \sum$ Ani $) /\left(\right.$ r $\sum$ Cat $+r \sum$ Ani $) \mid$

Where:

R.D \%: Relative difference

$\mathrm{r}$ : (epm) equivalent per million

$\mathrm{r} \sum$ Cat: Summation of positive ions concentrations in (epm) unit

$\mathrm{r} \sum$ Ani: Summation of negative ions concentrations in (epm) unit

According to Hem (1991), if ( $\mathrm{RD} \leq 5 \%)$ the results could be accepted for interpretations and if $(5 \%<$ $\mathrm{RD} \leq 10 \%$ ) the results could be accepted with risk, while if $\mathrm{RD} \%>10 \%$ cannot depended on the results in hydrochemical interpretations.

All results of relative difference (RD) are less 5\% which confirm the accuracy of chemical analysis.

WQI were calculated using Weighted Arithmetic Index Method to evaluate suitability for human drinking by using the following equations:

$$
\mathrm{WQI}=\sum \mathrm{Q}_{\mathrm{i}} \mathrm{W}_{\mathrm{i}} / \sum \mathrm{W}_{\mathrm{i}}
$$

Where:

$\mathrm{Q}_{\mathrm{i}}$ : Quality rating scale

$\mathrm{W}_{\mathrm{i}}$ : Unit weight 


$$
\mathrm{Q}_{\mathrm{i}}=\left[\left(\mathrm{V}_{\mathrm{i}}-\mathrm{V}_{0} / \mathrm{S}_{\mathrm{i}}-\mathrm{V}_{0}\right)\right] 100
$$

Where:

$\mathrm{V}_{\mathrm{i}}$ : Estimated concentration of ith parameter

$\mathrm{V}_{0}$ : The ideal value of this parameter in pure water $=0$ (except $\mathrm{pH}=7.0$ and $\left.\mathrm{DO}=14.6 \mathrm{mg} / \mathrm{l}\right)$.

$\mathrm{Si}$ : Standard value of ith parameter.

$$
\mathrm{W}_{\mathrm{i}}=\mathrm{K} / \mathrm{S}_{\mathrm{i}}
$$

Where:

$\mathrm{K}$ : A proportionality constant

$$
\mathrm{K}=1 / \sum(1 / S i)
$$

To evaluate the suitability of groundwater for irrigation purposes, TDS, Sodium adsorption ratio (SAR), and residual sodium carbonate (RSC) were calculated according to following equations:

$$
\begin{aligned}
& S A R=\frac{\mathrm{Na}}{\sqrt{(C a+M g) / 2}} \\
& \mathrm{RSC}=\left(\mathrm{HCO}_{3}^{-}+\mathrm{CO}_{3}^{2-}\right)-\left(\mathrm{Ca}^{2+}+\mathrm{Mg}^{2+}\right)
\end{aligned}
$$

\section{Results and Discussion}

The chemical components of hydrochemical parameters of springs water indicate That there are multi water sources where springs SP-3, SP-6, SP-7, SP-8, SP-11 and SP-15 were extract water from the Bai Hassan Formation which consists mainly of gravel and conglomerate. Springs SP-1, SP-4, SP14 and SP-23 were extract water mainly from quaternary deposits which have high portion of clay minerals. Remained springs extract mixed water from more than one formation in region (Table 1). The cation order is $\mathrm{Na}^{+}>\mathrm{Ca}^{2+}>\mathrm{Mg}^{2+}>\mathrm{K}^{+}$, where mean concentrations are $407 \mathrm{mg} / \mathrm{l}, 207 \mathrm{mg} / \mathrm{l}, 108$ and 35 $\mathrm{mg} / \mathrm{l}$, respectively. Sodium is a dominant cation in 24 spring samples which represent $96 \%$ of groundwater samples, while calcium dominates only in one sample which represent $4 \%$ of the samples. The anions order is $\mathrm{SO}_{4}{ }^{2-}>\mathrm{Cl}^{-}>\mathrm{HCO}_{3}{ }^{-}>\mathrm{NO}_{3}{ }^{-}$where mean concentrations are $805 \mathrm{mg} / \mathrm{l}, 516 \mathrm{mg} / \mathrm{l}, 343$ $\mathrm{mg} / \mathrm{l}$ and $1.6 \mathrm{mg} / \mathrm{l}$, respectively. Eighteen samples which represent $72 \%$ of all samples have a sulfate as a dominant anion, while chloride is a dominant in seven samples which represent $28 \%$ of all samples. The $\mathrm{pH}$ values range from 7.12 to 7.61 and the mean value is 7.22 indicates that the springs water is slightly alkaline. According to hydrochemical formula the water type of 16 samples which represent $64 \%$ of all samples is $\mathrm{NaSO}_{4}$ type, (2) samples which represent $8 \%$ of all samples is $\mathrm{CaSO}_{4}$ type, and (7) samples which represent $28 \%$ of all samples is $\mathrm{NaCl}$ type.Mean value of $\mathrm{EC}$ is $3920 \mu \mathrm{s} / \mathrm{cm}$ with standard deviation 2390 and the mean value of TDS is 2594 with standard deviation 1551 . The high standard deviation of EC and TDS values indicate that the springs water in the study area were extracted from more than one formation. Piper diagram was used to assess the hydrochemical facies of springs water. this diagram graphically represents some of the multiple variables associated with major cation and anion data and aid rapid determinations of similarities and differences in water samples (Piper, 1944). According to Langguth (1966), the Piper diagram can be divided into seven fields. It's clear as in Fig.2 that the most samples have been fallen in e field where earth alkaline water with increase portion of alkali with prevailing sulfate and chloride. Only S-P4, SP-13, SP-19, SP-20 and SP-25 have been fallen in $\mathrm{g}$ field where alkaline water with prevailing sulfate and chloride. 
Table 1. Chemical parameters for the springs water samples of the study area

\begin{tabular}{|c|c|c|c|c|c|c|c|c|c|c|c|c|c|c|c|c|}
\hline No & $\begin{array}{l}\text { Water } \\
\text { type }\end{array}$ & PH & $\begin{array}{c}\mathbf{E C} \\
\mu \mathrm{s} / \mathrm{cm}\end{array}$ & $\begin{array}{c}\text { T.D.S } \\
\text { mg/l }\end{array}$ & $\begin{array}{l}\mathrm{Ca}^{2+} \\
\mathrm{mg} / \mathrm{l}\end{array}$ & $\begin{array}{l}\mathrm{Mg}^{2+} \\
\mathrm{mg} / \mathrm{l}\end{array}$ & $\begin{array}{l}\mathrm{Na}^{+} \\
\mathrm{mg} / \mathrm{l}\end{array}$ & $\begin{array}{c}\mathrm{K}^{+} \\
\mathbf{m g} / \mathbf{l}\end{array}$ & $\begin{array}{l}\mathrm{C1}^{-} \\
\mathrm{mg} / \mathrm{l}\end{array}$ & $\begin{array}{c}\mathrm{HCO3}^{-} \\
\mathrm{mg} / \mathrm{l}\end{array}$ & $\begin{array}{c}\mathrm{SO}_{4}{ }^{-2} \\
\mathrm{mg} / \mathrm{l}\end{array}$ & $\begin{array}{c}\mathrm{NO3}^{-} \\
\mathrm{mg} / \mathrm{l}\end{array}$ & $\begin{array}{c}\text { TH } \\
\mathrm{mg} / \mathrm{l}\end{array}$ & WQI & SAR & RSC \\
\hline SP-1 & $\mathrm{NaSO}_{4}$ & 7.27 & 9770 & 6340 & 420 & 270 & 850 & 160 & 1150 & 750 & 1891 & 2.2 & 2160 & 493 & 7 & -31 \\
\hline SP-2 & $\mathrm{NaSO}_{4}$ & 7.2 & 4290 & 2800 & 240 & 120 & 470 & 9 & 543 & 472 & 825 & 2.1 & 1093 & 52 & 5 & -14 \\
\hline SP-3 & $\mathrm{CaSO}_{4}$ & 7.16 & 727 & 492 & 38 & 18 & 36 & 0.6 & 81 & 24 & 128 & 2.5 & 169 & 10 & 1 & -3 \\
\hline SP-4 & $\mathrm{NaSO}_{4}$ & 7.3 & 5550 & 3580 & 253 & 142 & 552 & 73 & 644 & 520 & 1140 & 1.4 & 1216 & 235 & 6 & -16 \\
\hline SP-5 & $\mathrm{NaSO}_{4}$ & 7.18 & 3910 & 2600 & 240 & 130 & 390 & 17 & 550 & 241 & 990 & 1.2 & 1134 & 73 & 4 & -19 \\
\hline SP-6 & $\mathrm{NaCl}$ & 7.24 & 599 & 395 & 38 & 16 & 50 & 2 & 95 & 20 & 112 & 2 & 161 & 16 & 1 & -3 \\
\hline SP-7 & $\mathrm{CaSO}_{4}$ & 7.15 & 689 & 470 & 39 & 20 & 38 & 0.8 & 83 & 24 & 130 & 2.3 & 180 & 10 & 1 & -3 \\
\hline SP-8 & $\mathrm{NaCl}$ & 7.15 & 443 & 300 & 30 & 10 & 51 & 0.6 & 92 & 16 & 72 & 1.1 & 116 & 9 & 2 & -2 \\
\hline SP-9 & $\mathrm{NaCl}$ & 7.2 & 4070 & 2660 & 266 & 105 & 414 & 16 & 590 & 457 & 769 & 1.2 & 1096 & 70 & 4 & -14 \\
\hline SP-10 & $\mathrm{NaSO}_{4}$ & 7.14 & 4250 & 2770 & 220 & 122 & 440 & 35 & 546 & 420 & 840 & 1.4 & 1051 & 121 & 5 & -14 \\
\hline SP-11 & $\mathrm{NaCl}$ & 7.25 & 602 & 410 & 38 & 18 & 72 & 4 & 120 & 19 & 90 & 1.1 & 169 & 22 & 2 & -3 \\
\hline SP-12 & $\mathrm{NaSO}_{4}$ & 7.61 & 4030 & 2600 & 257 & 89 & 392 & 7 & 490 & 441 & 780 & 1.3 & 1008 & 57 & 4 & -13 \\
\hline SP-13 & $\mathrm{NaSO}_{4}$ & 7.3 & 4420 & 2880 & 130 & 110 & 560 & 90 & 500 & 561 & 902 & 1.6 & 777 & 277 & 7 & -6 \\
\hline SP-14 & $\mathrm{NaSO}_{4}$ & 7.21 & 8580 & 5560 & 430 & 245 & 830 & 68 & 1120 & 614 & 1795 & 1.1 & 2082 & 234 & 6 & -32 \\
\hline SP-15 & $\mathrm{NaCl}$ & 7.24 & 799 & 580 & 61 & 38 & 75 & 2 & 183 & 23 & 181 & 1.4 & 309 & 18 & 2 & -6 \\
\hline SP-16 & $\mathrm{NaSO}_{4}$ & 7.14 & 4350 & 2800 & 235 & 114 & 465 & 8 & 538 & 468 & 820 & 1.2 & 1056 & 47 & 5 & -13 \\
\hline SP-17 & $\mathrm{NaSO}_{4}$ & 7.2 & 4360 & 2810 & 238 & 116 & 464 & 9 & 540 & 467 & 822 & 1.1 & 1072 & 51 & 5 & -14 \\
\hline SP-18 & $\mathrm{NaSO}_{4}$ & 7.17 & 5230 & 3380 & 292 & 140 & 540 & 95 & 625 & 475 & 1195 & 1.7 & 1305 & 293 & 5 & -18 \\
\hline SP-19 & $\mathrm{NaSO}_{4}$ & 7.14 & 3990 & 2570 & 190 & 125 & 470 & 35 & 580 & 114 & 1010 & 1.3 & 989 & 121 & 5 & -18 \\
\hline SP-20 & $\mathrm{NaSO}_{4}$ & 7.19 & 3740 & 2465 & 172 & 115 & 452 & 38 & 564 & 108 & 993 & 2.4 & 903 & 130 & 5 & -16 \\
\hline SP-21 & $\mathrm{NaCl}$ & 7.3 & 4000 & 2580 & 283 & 135 & 392 & 28 & 600 & 473 & 635 & 1.4 & 1262 & 108 & 4 & -17 \\
\hline SP-22 & $\mathrm{NaSO}_{4}$ & 7.22 & 4320 & 2790 & 245 & 118 & 472 & 10 & 550 & 472 & 850 & 1.6 & 1097 & 55 & 5 & -14 \\
\hline SP-23 & $\mathrm{NaSO}_{4}$ & 7.12 & 7190 & 4700 & 390 & 205 & 743 & 124 & 982 & 530 & 1650 & 1.7 & 1817 & 382 & 6 & -28 \\
\hline SP-24 & $\mathrm{NaCl}$ & 7.17 & 3570 & 3370 & 230 & 116 & 360 & 7 & 575 & 460 & 595 & 1.7 & 1052 & 44 & 4 & -13 \\
\hline SP-25 & $\mathrm{NaSO}_{4}$ & 7.2 & 4530 & 2960 & 210 & 82 & 610 & 60 & 560 & 415 & 922 & 1.8 & 862 & 192 & 7 & -10 \\
\hline Max & & 7.61 & 9770 & 6340 & 430 & 270 & 850 & 160 & 1150 & 750 & 1891 & 2.5 & 2160 & 493 & 7 & -2 \\
\hline Min & & 7.12 & 443 & 300 & 30 & 10 & 36 & 0.6 & 81 & 16 & 72 & 1.1 & 116 & 9 & 1 & -32 \\
\hline Mean & & 7.22 & 3920 & 2594 & 207 & 108 & 407 & 35 & 516 & 343 & 805 & 1.6 & 965 & 124 & 4 & -14 \\
\hline Std & & 0.10 & 2390 & 1551 & 117 & 66 & 238 & 43.6 & 291 & 227 & 507 & 0.44 & 560 & 128 & 1.9 & 8.2 \\
\hline
\end{tabular}

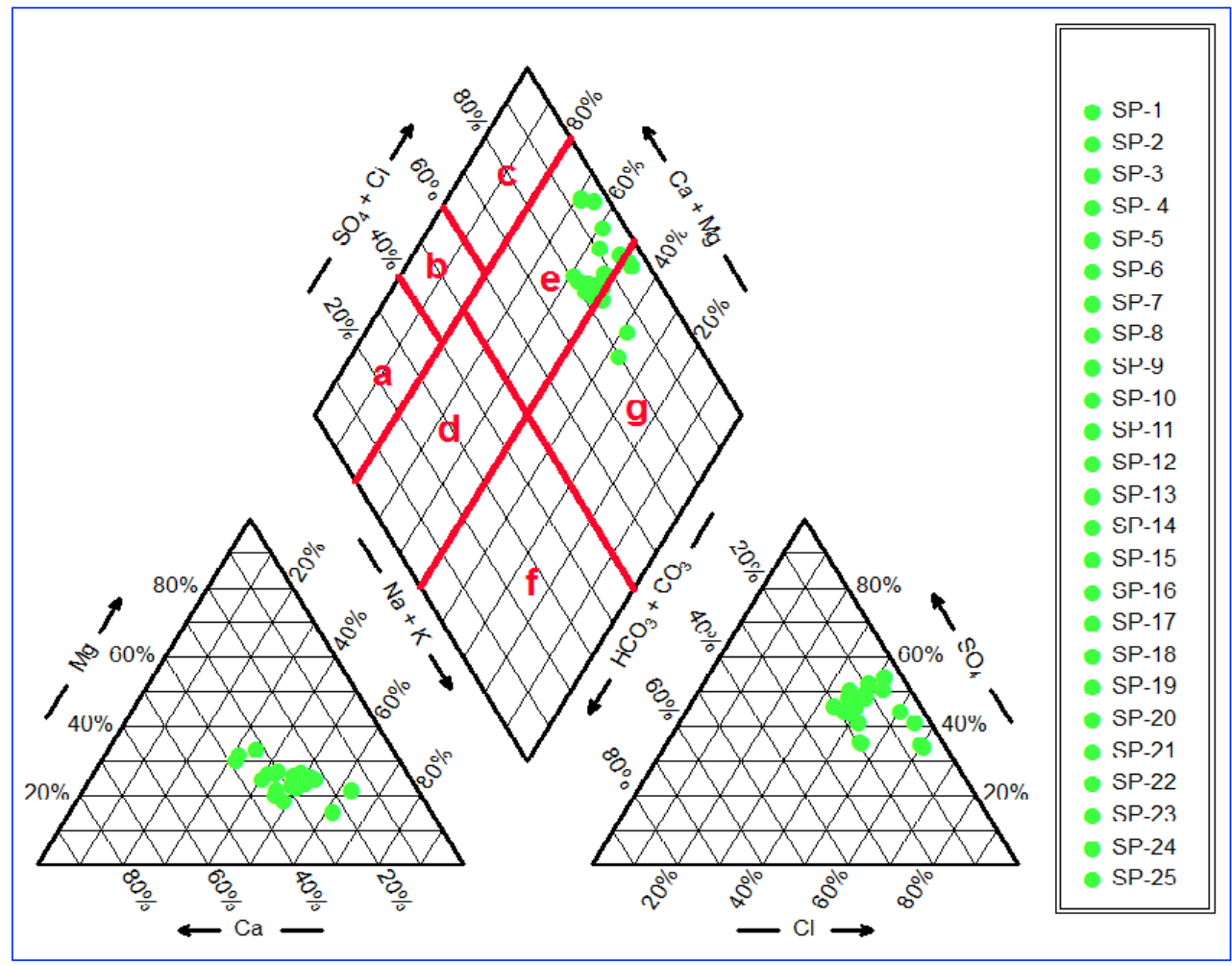

Fig. 2. Piper diagram for springs water samples of the study area

\subsection{Suitability of Water for Human Drinking}

The suitability of water for drinking is of great importance to the human life, and the impact of water on health derives principally from the consumption of water containing pathogenic organisms or 
toxic chemicals (WHO, 2012 in Awedh S.M. et al. 2016). WQI was evaluated by applying the Weighted Arithmetic Index method used by Brown et al. (1972). Parameters $\mathrm{pH}, \mathrm{TDS}, \mathrm{Ca}^{2+}, \mathrm{Mg}^{2+}, \mathrm{Na}^{+} . \mathrm{K}^{+} . \mathrm{Cl}^{-}$, $\mathrm{SO}_{4}{ }^{2-}, \mathrm{NO}_{3}{ }^{-}$, and $\mathrm{TH}$ used to calculate WQI for springs samples. All concentrations of the main positive and negative ions as well as values of $\mathrm{pH}$ and TDS for the samples SP-3, SP-6, SP-7, SP-8, SP-11 and SP-15 are compatible with the Iraqi, 2009 and WHO, 2012 human drinking standards, therefore (as that clear in Table 2) WQI values for these samples which represents $24 \%$ of all samples have been fallen in the grade A. samples SP-16 and SP-24 which represent 8\% of all samples have been fallen in grade B. The groundwater of eight water samples mentioned above have been extracted from the Bai Hassan Formation. Samples SP-2, SP-5, SP-9, SP-12, SP-17 and SP-22 which represent 24\% of all samples have been fallen in grade C. Springs water for this grade were extracted from both Bai Hassan and Injana formations together. Remaining water samples which represent $44 \%$ of all samples have been fallen in grade E, these water samples extracted from Fatha formation and quaternary deposits. According to WQI values the springs water in general not suitable for human drinking except samples mentioned above that fall in grades $\mathrm{A}$ and $\mathrm{B}$.

Table 2. Classification of water based on WQI

\begin{tabular}{lcc}
\hline WQI & Water Quality & Grade \\
\hline $0-25$ & Excellent & $\mathrm{A}$ \\
$26-50$ & Good & $\mathrm{B}$ \\
$51-75$ & Poor & $\mathrm{C}$ \\
$76-100$ & Very Poor & $\mathrm{D}$ \\
Above 100 & Unsuitable & $\mathrm{E}$ \\
\hline
\end{tabular}

\subsection{Suitability of Water for Irrigation Purposes}

The most important factors to increase the salinity of springs water are high percentage of evaporated water and the interaction with the formation materials.

The parameters EC, SAR, and RSC indices were used to identify the suitability of springs water for irrigation purposes. Plant roots absorb very little salt from the soil solution and the evaporation process increases the salinity of the water, both processes result increasing a concentration of salts in the soil water. If irrigation applied so sparingly that leaching is Ineffectual, or if drainage is inadequate, the soil will become saline and the growth of crops will be inhibited or prevented. Wilcox (1955) classified waters according to $\mathrm{EC}$ to four classes $(\mathrm{C} 1, \mathrm{C} 2, \mathrm{C} 3$, and $\mathrm{C} 4)$. The dividing points between classes are 250,750, and 2250 micromhos/ cm. According to Turgeon (2000), hazardus and limitation of these classes are as in Table 3.

Table 3. classification of springs water based on EC values according to Wilcox (1955) and Turgeon (2000)

\begin{tabular}{|c|c|c|}
\hline Groups & $\mathrm{EC}(\mu \mathrm{S} / \mathrm{cm})$ & Hazard and Limitations \\
\hline $\mathrm{C} 1$ & $<250$ & Low hazard; no detrimental effects on plants, and no soil build up expected. \\
\hline $\mathrm{C} 2$ & $250-750$ & $\begin{array}{l}\text { Sensitive plants may show stress; moderate leaching } \\
\text { prevents salt accumulation in soil. }\end{array}$ \\
\hline $\mathrm{C} 3$ & $750-2250$ & $\begin{array}{l}\text { Salinity will adversely affect most plants; requires selection of salt tolerant } \\
\text { plants, careful irrigation, good drainage, and leaching. }\end{array}$ \\
\hline $\mathrm{C} 4$ & $>2250$ & $\begin{array}{l}\text { Generally unacceptable for irrigation, except for very salt tolerant plants, } \\
\text { excellent drainage, frequent leaching, and intensive management. }\end{array}$ \\
\hline
\end{tabular}


According to electrical conductivity values springs samples SP-3, SP-6, SP-7, SP-8, SP-11, and SP-15 which represent 24 percent of all samples have been fallen in group C2 whereas remaining samples which represent 76 percent of all samples have been fallen in group $\mathrm{C} 4$; this indicate that the most of springs water unacceptable for irrigation except for very salt tolerant plants.

\subsection{Residual Sodium Carbonate (RSC)}

water having high concentration of $\mathrm{HCO}_{3}{ }^{-}$tends to precipitate $\mathrm{Ca}^{2+}$ and $\mathrm{Mg}^{2+}$ as $\mathrm{CaCO}_{3}$ and $\mathrm{MgCO}_{3}$ therefore the relative proportion of $\mathrm{Na}^{+}$in the water is increased in the form of sodium bicarbonate. According to Eaton (1950) and Richard (1954). Water is classified into three classes according to RSC as that clear in Table 4 . When the RSC values are more than $2.5 \mathrm{meq} / 1$ the water are unsuitable for irrigation. RSC values for springs samples are less than 1.25 therefore the water is suitable for irrigation purposes according to this index.

Table 4. classification of springs water based on RSC values according to Eaton (1950)

\begin{tabular}{ccc}
\hline RSC meq/l & Irrigation Class & Number of samples \\
\hline$<1.25$ & Safe & All samples \\
$1.25-2.50$ & Marginal & -- \\
$>2.50$ & Unsuitable & -- \\
\hline
\end{tabular}

\subsection{Sodium Adsorption Ratio (SAR)}

An elevated salinity causes a reduction in the osmotic activity of plants and affects the absorption of nutrients and water from the soil (Saleh et al., 1999 in Al-Harahshah et al., 2020). SAR is considered as an indicator of the ratio of sodium ion to calcium and magnesium ions in the sample. The high values of SAR are an indication of the degree of substitution of sodium in the water with calcium and magnesium in the soil. Richard (1954) classified the water according to SAR values to four classes as in Table 5. All springs samples have SAR values less than 10 therefore they considered an excellent for irrigation in respect to this index.

Table 5. classification of springs water based on SAR values according to Richard (1954)

\begin{tabular}{lccc}
\hline SAR & Symbol & Quality of water & Samples \\
\hline$<10$ & $\mathrm{~S} 1$ & Excellent & All samples \\
$11-18$ & $\mathrm{~S} 2$ & Good & -- \\
$19-26$ & $\mathrm{~S} 3$ & Doubtful & -- \\
$>26$ & $\mathrm{~S} 4$ & Unsuitable & -- \\
\hline
\end{tabular}

Richard diagram is a combination between the classification according to EC on $\mathrm{X}$ axis and the classification according to SAR on $\mathrm{Y}$ axis. This diagram divides water to sixteen classes for irrigation suitability. Springs water samples SP-3, SP-6, SP-7, SP-8, and SP-11 which represent $20 \%$ of all samples have been fallen in $\mathrm{C} 2 \mathrm{~S} 1$ class where they are good for irrigation. Sample SP-15 have been fallen in C3S1 class where it is admissible for irrigation. Samples SP-2, SP-4, SP-5, SP-9, SP-10, SP-12, SP-13, SP-16, SP-17, SP-18, SP-19, SP-20, SP-21, SP-22, SP-23, SP-24, and SP-25 which represent 68\% of all samples have been fallen in C4S2 class where they are poor for irrigation. Samples SP-1 and SP-14 which represent $8 \%$ of all samples have been fallen in $\mathrm{C} 4 \mathrm{~S} 3$ class where they are very poor for irrigation (Table 6 and Fig.3). 
Table 6. Separation of springs water samples on Richard Diagram classes

\begin{tabular}{lcc}
\hline Water classes & Suitability for irrigation & Springs samples \\
\hline C1S1 & Excellent & -- \\
C1S2 & Good & -- \\
C1S3 & Admissible & -- \\
C1S4 & Poor & -- \\
C2S1 & Good & SP-3, SP-6, SP-7, SP-8, SP-11 \\
C2S2 & Good & -- \\
C2S3 & Marginal & -- \\
C2S4 & Admissible & -- \\
C3S1 & Admissible & SP-15 \\
C3S2 & Marginal & -- \\
C3S3 & Marginal & -- \\
C3S4 & Poor & -- \\
C4S1 & Poor & SP-5 \\
C4S2 & Poor & SP-2, SP-4, SP-9, SP-10, SP-12, SP-13, SP-16, SP-17, SP-18, \\
C4S3 & SP-19, SP-20, SP-21, SP-22, SP-23, SP-24, SP-25 \\
C4S4 & Very Poor & SP-1, SP-14 \\
\hline
\end{tabular}

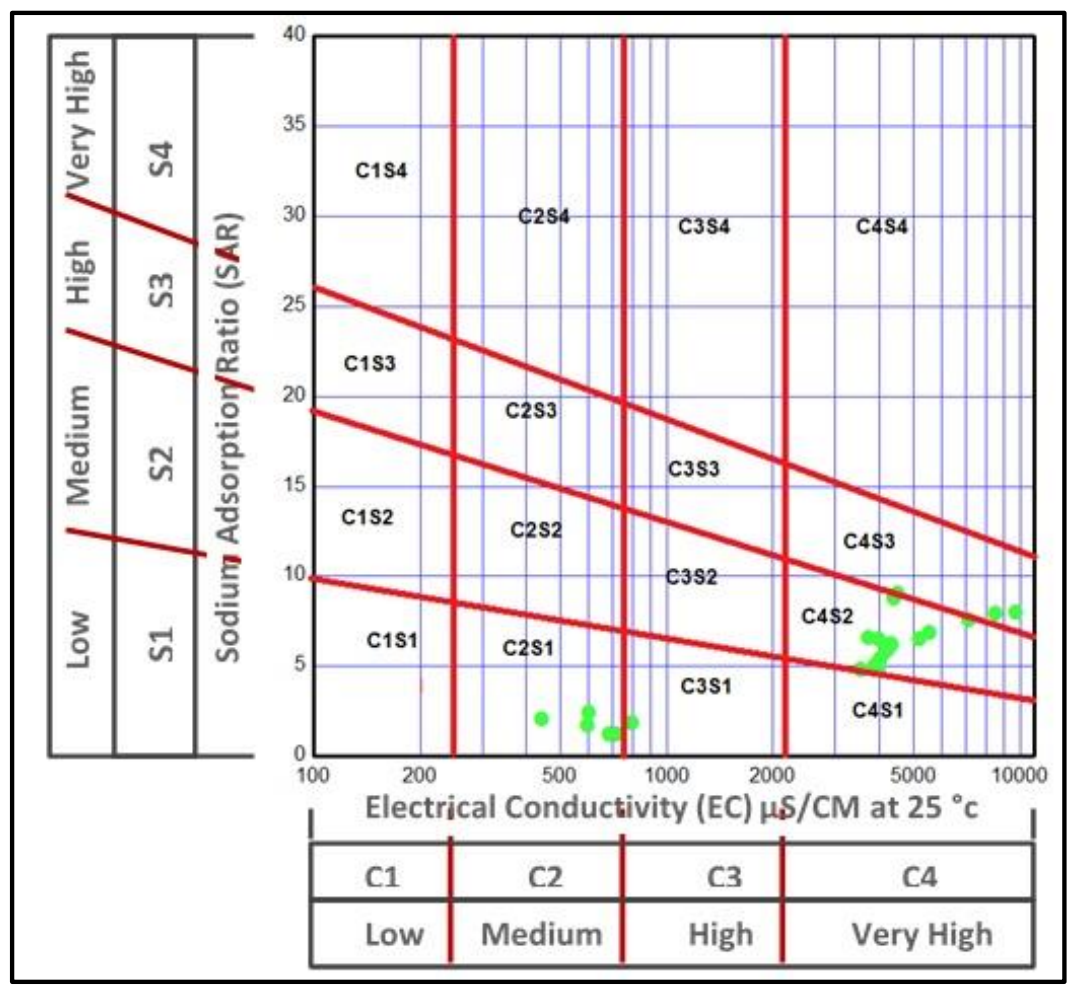

Fig. 3. Richard diagram of springs water samples for the study area

\section{Conclusions}

Qazania area is an important agricultural area in Diala governorate-east Iraq. Springs water in the area is extracted from four geological formations, Fatha, Ingana, Mukdadia, and Bai Hassan in addition 
to quaternary deposits. Dominat cation is $\mathrm{Na}^{+}$followed by $\mathrm{Ca}^{2+}, \mathrm{Mg}^{2+}$ then $\mathrm{K}^{+}$whereas dominant anion $\mathrm{SO}_{4}{ }^{2-}$ followed by $\mathrm{Cl}^{-}, \mathrm{HCO}^{-}$then $\mathrm{NO}^{-}$. The dominant water type is $\mathrm{NaSO} 4$ followed by $\mathrm{NaCl}$ type. According to WQI values, water for only eight springs considered safe for human drinking in respect of chemical constituents. Only six samples are suitable for irrigation purposes.

\section{Acknowledgements}

The authors are very grateful to Mr. Basim K. M. Al-Mashadani the Head of Diala Branch of General Commission for Groundwater for providing the supplies for field work, also we are very greatful to Mrs. Nidal Hadi Head of the Geology Department in the General Commission for Groundwater. The authors are very grateful to the Editor in Chief Prof. Dr. Salih M. Awadh, the Secreatry of Journal Mr. Samir R. Hijab and the Technical Editors for their great efforts and valuable comments.

\section{References}

Al-Harahshah, S., Al-Raggad M., Al-Shdaifat A. and Al-Wreikat M., 2020. Hydrochemical evaluation of the Azraq unconfined aquifer, Jordan., Iraqi Geological Journal 53 (2A), 1-18

Ali, M. E., Abdel-Hameed, M., 2018. The potential of nitrate removal from groundwater of Bani-Suif west area, Egypt using nanocomposite reverse osmosis membranes. Journal of Basic and Environmental Sciences 5, 230-239.

Awadh, S. M., Al-Mimar, H. S., Yaseen, Z. M., 2020. Groundwater availability and water demand sustainability over the upper mega aquifers of Arabian Peninsula and west region of Iraq. Environment, Development and Sustainability, 1-21

Awadh, S. M., Al-Kilabi, J. A. Abdulhussein, F. M., 2016, Assessment of groundwater quality using water quality index in Al-Hawija area, Northern Iraq, Iraqi Geological Journal 39-49(1), 67-76.

Awadh, S. M., Abdulhussein, F. M., Al-Kilabi, J. A., 2016. Hydrogeochemical processes and water-rock interaction of groundwater in al-Dammam aquifer at Bahr al-Najaf, central., Iraqi Bulletin of Geology and Mining 12(1), 1-15.

Barwary, A. M., 1991. The Geology of Mandali Quadrangle Sheet NI-38-11 (GM-21) scale 1:250 000.

Brown, R., Mccleiland, N., Deiniger, R., Oconnor, M., 1972. Water quality index-crossing the physical barrier. In: Proceedings of international conference on water pollution research, Jerusalem, 787-797.

Chilton, P. J., Lawrence, A. R. and Barker, J. A., 1994. Pesticides in groundwater: some preliminary observations on behaviour and transport in tropical environments. British Geological Survey, Maclean Building, Wallingford, Oxfordshire, UK.

Dikeogu, T. C., Okeke, O. C., Ogbekhiulu, L. O., Ogbenna, P. C., 2018. Major ion chemistry and hydrochemical processes of Ngeneagu spring water at Akpugoeze Oji River, Enugu, southeastern Nigeria., International Journal of Advanced Academic Research Sciences, Technology \& Engineering, 4 (2).

Eaton, F. M., 1950. Significance of carbonate irrigation water. Soils Science 69(2),123-133.

Fakhre, H. N. and Abdulhussein, F. M., 2020. hydrochemical assessment of groundwater and some springs in Qazaniyah Area, Diyala Province, East of Iraq., Iraqi Journal of Science 61(9), 2277-2292.

Hem, J. D., 1991. Study and interpretation of the chemical characteristics of natural water. USGS Water Supply, 2254, 263p.

Al-Sudani, H.I., 2018. Hydrochemical evaluation and utilization of groundwater in Khanaqin Area, Diyala Governorate, East of Iraq., Iraqi Journal of Science 59(4C), 2279-2288.

Langguth, H. R., 1966. Die Grundwasser verhältnisse im Bereich des Velberter Sattels, Rheinisches Schiefergebirge. Der Minister für Ernährung, Landwirtschaft und Forsten, NRW, Düsseldorf. (unpublished).

Niaz, A., Khan, M. R., Ijaz, U., Yasin, M., Hameed, F., 2018. Determination of groundwater potential by using geoelectrical method and petrographic analysis in Rawalakot and adjacent areas of Azad Kashmir, subHimalayas, Pakistan. Arabian Journal of Geosciences 11(16), 468.

Parsons, 1955. Groundwater Resources of Iraq, Volume 1, Khanaqin-Jassan area. 
Piper, A. M., 1944. A graphical procedure in the geochemical interpretation of water analysis. Transactions American Geophysical union. 25, 914-928.

Richard, L. A., 1954. Diagnosis and Improvement of Saline Alkali Soils: Agriculture, Handbook. US Department of Agriculture, Washington, D. C., 160: 60

Saleh, A., AL-Ruwaih, F., and Shehata, M., 1999. Hydrogeochemical processes operating within the main aquifers of Kuwait. Journal Arid Environment, 42,195-209.

Scanlon, B., Keese, K., Flint, A., Flint, L., Gaye, C., Edmunds, W. Simmers, 2006. Global synthesis of groundwater recharge in semiarid and arid regions. Hydrological Process 20, 3335-3370. Department of Agriculture, Washington, 969.

Shiklomanov, I. A., 1996. Assessment of water resources and availability in the world. Scientific and Technical Report. St. Petersburg, Russia, State Hydrological Institute. 127pp.

Sissakian, V. K., Capigian, A. O., Al-Ansari, N., and Knutsson, S., 2017. Characters and types of alluvial fans in the middle and eastern parts of Iraq., Journal of Earth Sciences and Geotechnical Engineering 7(3), 115140

Turgeon, A. J., 2000. Irrigation Water Quality, College of Agricultural sciences, Pennsylvania State University, USA.

WHO, World Health Organization, 2012. Rapid Assessment of Drinking Water Quality, Handbook for Implementation, 138pp.

Wilcox, L. V., 1955. Classification and Use of Irrigation Waters., U. S. Department of Agriculture. 